\title{
RESENSI BOOKCHAPTER \\ BUNGA RAMPAI GUBAHAN AKADEMISI AKUNTANSI DAN MANAJEMEN 2019
}

\author{
Ahadiyah Lailatul IImi \\ Universitas Nahdlatul Ulama Sidoarjo
}

\section{Pengantar}

Segenap dosen Universitas Bahaudin Mudhary Madura (UNIBA Madura) pada tahun 2019 menulis dua bookchapter. Tulisan ini bermaksud untuk memberikan resensi untuk tulisan-tulisan didalam bookchapter tersebut.

\section{Bunga Rampai Gubahan Akademisi Akuntansi 2019}

Tabel 1

\begin{tabular}{|l|l|}
\hline \multicolumn{1}{|c|}{ Identitas Buku } & \multicolumn{1}{c|}{ Keterangan } \\
\hline Judul Buku & Bunga Rampai Gubahan Akademisi Akuntansi 2019 \\
\hline Penulis & $\begin{array}{l}\text { Kartika Rusnindita, Subaida, Liahmad, Nadiyah } \\
\text { Masithah Sani, Istiyanatul Mahbubah }\end{array}$ \\
\hline Gaya penulisan & IImiah \\
\hline Penerbit & STIEBA Madura Press \\
\hline Tahun & 2019 \\
\hline ISBN & $978-623-7385-01-1$ \\
\hline Jumlah halaman & 75 \\
\hline
\end{tabular}

Artikel berjudul "Studi Fenomena Partisipasi Anggaran, Komitmen Organisasi serta Asimetri Informasi yang Berpotensi Terjadinya Senjangan Anggaran" karya penulis Kartika Rusnindita mengulas tentang lemahnya komitmen organisasi yang dimiliki karyawan suatu perusahaan, partisipasi anggaran yang kurang baik dari bawahan/karyawan perusahaan, dan terdapat asimetri informasi pada penyusunan anggaran perusahaan dapat berpotensi menimbulkan senjangan anggaran serta mengakibatkan implementasi angggaran tidak optimal (Rusnindita, 2019).

Penulis Istiyanatul Mahbubah dengan tulisan bertajuk "Peran ECommerce Terhadap Peningkatan Pendapatan Usaha Mikro Kecil dan Menengah" mengajak kita untuk memahami E-commerce untuk mengembangkan lingkungan usaha yang kondusif bagi usaha mikro, kecil dan menengah agar bisa meningkatkan daya saing dengan menciptakan peluang usaha yang luas (Mahbubah, 2019).

Tulisan berjudul "Mengenal Fraud: Bentuk dan Ciri-Cirinya" hasil pemikiran Subaida bercerita mengenai ragam bentuk, pelaku dan ciri-ciri pelaku fraud agar masyarakat dapat berhati-hati dan dapat membuat 
kebijakan supaya perusahaan dapat mencegah dan mendeteksi terjadinya fraud (Subaida, 2019).

Pemikiran Nadiyah Masithah Sani mengenai "Sudut Pandang Etika dan Moral Korupsi dari Perspektif Akuntansi” mengulas tentang korupsi sebagai perbuatan mencuri, namun lebih terlihat elegan. Karena korupsi bukan hanya menyalahgunakan uang namun juga bisa jadi mencuri waktu atau pekerjaan (Sani, 2019).

Pemikiran berjudul "Teori Akuntansi: Pengertian, Peran, Praktik, Asumsi dan Metode" hasil perenungan peneliti Liahmad menelusuri tentang teori akuntansi sebagai metode yang dapat dipergunakan yaitu metode deskriptif (pragmatic), psychological pragmatic, metode normatif dan metode positif (Liahmad, 2019).

\section{Bunga Rampai Gubahan Akademisi Manajemen 2019}

Tabel 2

\begin{tabular}{|l|l|}
\hline \multicolumn{1}{|c|}{ Identitas Buku } & \multicolumn{1}{|c|}{ Keterangan } \\
\hline Judul Buku & $\begin{array}{l}\text { Bunga Rampai Gubahan Akademisi Manajemen } \\
2019\end{array}$ \\
\hline Penulis & $\begin{array}{l}\text { Alvin Arifin, Ach. Zuhri, Humera Asad Ullah Khan, } \\
\text { Mahmud Yunus }\end{array}$ \\
\hline Gaya penulisan & Ilmiah \\
\hline Penerbit & STIEBA Madura Press \\
\hline Tahun & 2019 \\
\hline ISBN & $978-623-7385-02-8$ \\
\hline Jumlah halaman & 54 \\
\hline
\end{tabular}

Artikel berjudul "Manajemen Sumber Daya Manusia pada Masyarakat Desa" karya penulis Alvin Arifin mengulas tentang mensejahteraan desa dengan pemanfaatan sumber daya yang ada di desa dengan dukungan dari masyarakat yang secara aktif ikut berpartisipasi akan menjadikan percepatan pertumbuhan ekonomi (Arifin, 2019).

Penulis Ach. Zuhri dengan tulisan bertajuk "VUCA (- \& +) Kepemimpinan Wirausaha Era Disrupsi Digital" mengajak kita untuk memahami disrupsi digital berdampak negatif terhadap dunia bisnis utamanya kepada manajemen kepemimpinan saat ini, yang biasa dikenal dengan istilah VUCA (Volatile, Uncertainty, Complexity, \& Ambiguity) (Zuhri, 2019).

Tulisan berjudul "Tantangan dalam Manajemen Pemasaran" hasil pemikiran Humera Asad Ullah Khan bercerita mengenai tantangan yang dihadapi oleh manajemen dan manajer pemasaran terhadap lingkungan yang selalu berkembang secara dinamis, bergerak sesuai dengan tantangan global yang ada dalam masyarakat kita saat ini (Khan, 2019). 
Pemikiran Mahmud Yunus mengenai "Bagaimana Kepemimpinan Bekerja di dalam Organisasi" mengulas tentang agregasi kepemimpinan sebagai kekuatan untuk mempengaruhi seseorang, apakah itu dalam praktik atau tidak (Yunus, 2019).

\section{Penutup}

Karya buku bunga rampai berjudul "Bunga Rampai Gubahan Akademisi Akuntansi 2019" dan "Bunga Rampai Gubahan Akademisi Akuntansi 2019" menambah perbendaharaan pengetahuan akuntansi dan manajemen di Indoensia.

\section{References}

Arifin, A. (2019). Manajemen Sumber Daya Manusia pada Masyarakat Desa. In Bunga Rampai Gubahan Akademisi Manajemen 2019. Sumenep: STIEBA Madura Press.

Khan, H. A. U. (2019). Tantangan dalam Manajemen Pemasaran. In Bunga Rampai Gubahan Akademisi Manajemen 2019. Sumenep: STIEBA Madura Press.

Liahmad. (2019). Teori Akuntansi: Pengertian, Peran, Praktik, Asumsi dan Metode. In Bunga Rampai Gubahan Akademisi Akuntansi 2019. Sumenep: STIEBA Madura Press.

Mahbubah, I. (2019). Peran E-Commerce Terhadap Peningkatan Pendapatan Usaha Mikro Kecil dan Menengah. In Bunga Rampai Gubahan Akademisi Akuntansi 2019. Sumenep: STIEBA Madura Press.

Rusnindita, K. (2019). Studi Fenomena Partisipasi Anggaran, Komitmen Organisasi serta Asimetri Informasi yang Berpotensi Terjadinya Senjangan Anggaran. In Bunga Rampai Gubahan Akademisi Akuntansi 2019. Sumenep: STIEBA Madura Press.

Sani, N. M. (2019). Sudut Pandang Etika dan Moral Korupsi dari Perspektif Akuntansi. In Bunga Rampai Gubahan Akademisi Akuntansi 2019. Sumenep: STIEBA Madura Press.

Subaida. (2019). Mengenal Fraud: Bentuk dan Ciri-Cirinya. In Bunga Rampai Gubahan Akademisi Akuntansi 2019. Sumenep: STIEBA Madura Press.

Yunus, M. (2019). Bagaimana Kepemimpinan Bekerja di Dalam Organisasi. In Bunga Rampai Gubahan Akademisi Manajemen 2019. Sumenep: STIEBA Madura Press.

Zuhri, A. (2019). VUCA (- \& +) Kepemimpinan Wirausaha Era Disrupsi Digital. In Bunga Rampai Gubahan Akademisi Manajemen 2019. Sumenep: STIEBA Madura Press. 